After having studied the digestion of a certain number of protein feeds (fish meal, barley, pea-nut), we compared, during two experiments, the kinetics of absorption of free L-lysine and of the lysine proceeding from the digestion of wheat or sunflower, we observed that for the diets studied, supplemented or not by free L-lysine, the maxima of lysine absorption appear at the same time.

During another experiment, we used five fistulated pigs fed a diet containing DL-methionine supplemented herring meal and we compared the absorption rate of free methionine with that of methionine arising from the digestion of fish proteins. For this purpose we used ${ }^{35} \mathrm{~S}$ DL-methionine injected into the duodenum a little after the beginning of the meal by means of a small cannula placed at the same time as the catheter of the portal vein.

The contents of labelled methionine and of total free methionine of the portal blood are very high already in the first samples taken ${ }_{5}$ minutes after the ingestion and then they diminish regularly. The specific radioactivity of the blood methionine is always definitely lower than that of the injected methionine and decreases more rapidly than the content of total free methionine in the blood. Consequently, it seems that the absorption of the methionine arising from digestion of fish meal begins at the same time as that of the free methionine injected into the duodenum, but lasts longer as for most of the other amino acids.

\title{
ÉTUde DEs VARIATIONS POSTPRANDIALES DE LA GLYCÉMIE ET DE L'AMinoACIdémie MésentéRIQUE GHEZ LE PORC
}

\author{
M. PAWLAK, P. THIVEND * et R. PION
}

avec la collaboration technique de P. Vaugelade et P. Vaissade

Station d'Études des Métabolismes,

* Station de Recherches sur l'Élevage des Ruminants, Centre de Recherches de Clermont-Ferrand, I. N. R. A., 63 - Saint-Genès-Champanelle

Trois porcs adultes ( $\mathrm{A}, \mathrm{B}$ et $\mathrm{C}$ ) pesant environ $80 \mathrm{~kg}$ chacun ont été munis d'un cathéter permanent placé dans une portion de la veine mésentérique drainant approximativement les six premiers mètres du jéjunum. L'animal A était porteur en outre d'un cathéter permanent placé dans la veine porte et l'animal $\mathrm{C}$, d'un cathéter permanent placé dans la veine jugulaire. Les animaux recevaient un régime comprenant $84 \mathrm{p}$. Ioo d'orge, $2 \mathrm{p}$. Ioo de tourteau de soja, $5 \mathrm{p}$. 100 de farine de poisson, $5 \mathrm{p}$. Ioo de son et $4 \mathrm{p}$. Ioo d'un mélange minéral et vitaminique. Les quantités d'aliment ingéré par repas ont été en moyenne de $\mathrm{I} 350 \mathrm{~g}$ de matière sèche (700 $\mathrm{g}$ d'amidon) pour les porcs A et B et de I I $50 \mathrm{~g}$ (600 $\mathrm{g}$ d'amidon) pour l'animal $\mathrm{C}$.

Dix-huit séries de mesures ont été effectuées au niveau des veines mésentériques (I 2) porte (4) et jugulaire (2) pour étudier les variations de la glycémie. Chaque série comprenait en moyenne Io prélèvements effectués sur une période de 7 heures après le repas. Le glucose a été dosé par la méthode enzymatique de Hill et Kessler (I96I) adaptée à l'auto-analyseur Technicon. Nous avons observé que la glycémie mésentérique est toujours supérieure à la glycémie porte et à la glycémie jugulaire (respectivement de 46 et de $80 \mathrm{p}$. 100). A un instant donné, la glycémie mésentérique est d'autant plus faible que le prélèvement est effectué plus près de la veine porte. Ce phénomène de dilution semble indiquer que la digestion de l'orge a lieu en majeure partie dans 
la portion de jéjunum correspondant au sang mésentérique que nous avons prélevé. La glycémie mésentérique n'évolue pas de façon régulière mais présente des maxima qui se situent approximativement $\mathrm{I} \mathrm{h} 30,4$ et 6 heures après le repas. Elle varie également avec les quantités d'amidon ingéré.

La cinétique de l'aminoacidémie (PAwLAK et PIon, I968) mesurée dans la veine mésentérique au cours de la digestion a été étudiée sur un animal. Les maxima, de l'ordre de 150 à 300 p. roo des concentrations đu sang de l'animal à jeun, apparaissent entre 30 et 45 minutes après le début du repas. Les teneurs de la plupart des acides aminés restent généralement élevées pendant 90 minutes, puis diminuent pour augmenter à nouveau environ 7 heures après le début du repas.

L'absorption des acides aminés semble commencer en même temps que celle du glucose; elle est cependant plus étalée dans le temps.

Les concentrations de la plupart des acides aminés dans le sang mésentérique sont supérieures de ro à $20 \mathrm{p}$. Ioo à leurs concentrations dans le sang porte prélevé au même moment. Les deux exceptions les plus marquantes sont l'acide glutamique qui est en concentration très élevée dans le sang mésentérique, et la lysine qui se trouve en concentration identique aux deux niveaux.

\section{SUMMARY}

\section{STUDY OF THE POSTPRANDIAI, VARIATIONS OF MESENTERIC GLYCEMIA AND AMINOACIDEMTA IN THE PIG}

Three adult pigs (A, B, C) weighing about $80 \mathrm{~kg}$ each were fitted with a permanent catheter placed in the mesenteric vein in a region draining approximately the first six meters of the jejunum. Animal $\mathrm{A}$ was also fitted with a permanent catheter in the portal vein and animal $\mathrm{C}$ with a permanent catheter in the jugular vein. The animals received a diet containing $84 \mathrm{p}$. Ioo barley, 2 p. Ioo soybean oil meal, 5 p. I0o fish meal, 5 p. 10o bran and 4 p. 100 of a mineral and vitamin mixture. The mean intake per meal was I $35^{\circ} \mathrm{g}$ dry matter (7oo $\mathrm{g}$ starch) for the pigs $\mathrm{A}$ and $\mathrm{B}$ and $\mathrm{I} 150 \mathrm{~g}$ ( $600 \mathrm{~g}$ starch) for the animal $\mathrm{C}$.

I 8 series of measurements were carried out at the level of the mesenteric (I2), portal (4) and jugular (2) veins in order to study the glycemia variations. Each series included, on average, Io samples obtained during a period of 7 hours after the meal. Glucose was determined by the enzymatic method of HILI and KessLer (I96I) adapted to the auto-analyser Technicon. We observed that mesenteric glycemia is always higher than portal and jugular glycemia ( 46 and 80 p. 100 respectively). At a given time, the nearer the portal vein the sample is taken, the lower is the mesenteric glycemia. This dilution phenomenon seems to indicate that the digestion of barley takes mainly place in the region of the jejunum corresponding to the mesenteric blood obtained. The mesenteric glycemia does not develop regularly, but shows maxima localized approximately $\mathrm{I} .3^{\circ}, 4$ and 6 hours after meal. It also varies with the amounts of starch ingested.

The aminoacidemia kinetic (PAWLAK and PION, 1968) measured in the mesenteric vein during digestion was studied in one animal. The maxima (about 150 to $300 \mathrm{p}$. Ioo of the blood concentrations of the fasting animal) appear between 30 and 45 minutes after the beginning of the meal. The amounts of most amino acids remain generally high during 90 minutes, afterwards they decrease and then increase again after about 7 hours after the beginning of the meal.

The absorption of amino acids seems to begin at the same time as that of glucose; it lasts, however, longer.

The concentrations of most amino acids in the mesenteric blood are ro to $20 \mathrm{p}$. 100 higher than their concentrations in the portal blood obtained at the same time. The two most important exceptions are glutamic acid, the concentration of which is very high in the mesenteric blood and lysine, the concentrations of which are identical in the mesenteric and portal blood. 


\title{
RÉFÉRENCES BIBLIOGRAPHIQUES
}

Hill J. B., Kessler J., I96r. An automated determination of glucose utilizing a glucose-oxydase, peroxydase system. J. Lab. Clin. Med., 57, 907-909.

Pawlak M., Pion R., I968. Influence de la supplémentation des protéines du blé par des doses croissantes de lysine sur la teneur en acides aminés libres du sang et du muscle du rat en croissance. Ann. Biol. anim. Bioch. Biophys., 8, 517-530.

\section{absorption de l'azote unéique et ammonacal Chez Le porc Résultats phéliminaines}

\author{
A. RÉRAT et A. AUMAITRE \\ Station de Recherches sur l'Élevage des Porcs, \\ Centre national de Recherches zootechniques, I. N. R. A., \\ 78 - Jouy-en-Josas
}

La substitution d'urée à une fraction des matières azotées du régime a fait l'objet d'un certain nombre d'études récentes chez les monogastriques. La plupart des auteurs conclue à une très faible incorporation de l'azote d'origine uréique aux tissus de l'organisme, mais les résultats qu'ils fournissent sont assez contradictoires.

A fin de comprendre comment l'urée peut être utilisée par l'organisme à des fins métaboliques, il serait bon de préciser les premières étapes de son métabolisme au cours du transit digestif, de sa résorption par l'intestin et de son passage par le foie. C'est pourquoi il nous a semblé intéressant de décrire les variations de l'urémie et de l'ammoniémie dans le sang porte et dans le sang périphérique au cours de la digestion de repas bien équilibrés contenant ou non de l'urée. Le sang était obtenu en continu à partir de la veine porte et de la veine jugulaire selon une technique décrite par ailleurs (Aumaitre et al., 1969). Le dosage de l'ammoniaque dans le sang était réalisé à l'aide de la technique de Assous et al. (1960), celui de l'urée par la technique de Marsh et al. (1965). Les premiers résultats obtenus sur 3 porcs de race Large White sont les suivants :

- Les concentrations d'urée et d'ammoniaque dans le sang prélevé avant les repas expérimentaux varient d'un jour à l'autre dans des proportions qui ne sont pas négligeables (urée : I 25 à $220 \mathrm{mg} / \mathrm{l}$ dans le sang porte, I 25 à $260 \mathrm{mg} / \mathrm{l}$ dans le sang jugulaire, ammoni aque 1,7 à $3 \mathrm{mg} / \mathrm{l}$ dans le sang porte, $o, \mathrm{I}$ à 0,2 dans le sang jugulaire).

- En l'absence d'urée dans le régime, la concentration d'urée dans le sang augmente lentement après le repas, mais cet accroissement est faible, atteignant environ $4^{\circ} \mathrm{P}$. Ioo $_{4}$ heures après le repas. La concentration d'urée dans la veine porte est légèrement plus faible que celle présente dans le sang jugulaire, ce fait pouvant être expliqué par l'excrétion d'urée dans l'intestin grêle.

Par contre, l'ammoniémie croît dans des proportions beaucoup plus importantes, tant dans le sang porte que dans le sang jugulaire, l'augmentation atteignant environ $25^{\circ} \mathrm{p}$. I0o, 3 heures après le repas. La concentration d'ammoniaque présente dans le sang jugulaire est environ Io fois plus faible que celle trouvée dans le sang porte, ce qui s'explique par la métabolisation hépatique de l'ammoniaque. 